\title{
A classificação dos créditos falimentares e a função social da empresa na falência
}

\section{The classification of bankruptcy claims and the social function of the company in bankruptcy}

\author{
Carla Bonomo'; Vitor Ferreira de Campos ${ }^{2}$
}

\section{Resumo}

Este artigo tem a intenção de abrir ou trazer à luz para um debate acerca dos créditos falimentares sob a égide da Lei 11.101/2005, haja vista que toda classificação creditícia urgia uma atualização moderna, com o fulcro no Direito Social, o que somente ocorreu com a Nova Lei de Falências. O estudo realizado foi exploratório e qualitativo, tendo como estratégia a abordagem de cada crédito, epigrafando as diferenças da recente Legislação com o antigo Decreto 7.661/1945, evidenciando-se o porquê da ordem de pagamento estruturada pela lei em comento, inclusive com a abordagem de temas polêmicos como a limitação ao recebimento de até cento e cinquenta salários mínimos dos créditos trabalhistas, e ao final, a comprovação de que a classificação dos créditos decorrentes da Lei 11.101/2005 faz concretizar a função social da empresa, até mesmo na falência, posto que valoriza e contempla o respeito aos credores de acordo com a natureza de seus créditos.

Palavras-chave: Direito falimentar. Lei 11.101/2005. Classificação dos créditos. Função social da empresa.

\begin{abstract}
This article intends to open or bring to light a debate about the bankruptcy claims under the aegis of Law 11.101/2005, considering that all credit rating urged a modern update, centered in Social Law, which only occurred with the New Bankruptcy Law. The study was exploratory and qualitative, with the strategy to approach each claim, denominating the differences of recent legislation with former Decree $7.661 / 1945$, demonstrating why the payment order structured by the law under discussion, including the approach of controversial issues such as limiting the receipt of one hundred and fifty minimum salaries of workers' claims, and finally, proof that the classification of credits arising from Law 11.101/2005 fulfill the social function of the company, even in bankruptcy, since it values and reflects the respect to creditors according to the nature of their claims.
\end{abstract}

Keywords: Bankruptcy Law.Law 11.101/2005. Classification of claims. Social function of the company.

\footnotetext{
${ }^{1}$ Realizou parte da dissertação de Mestrado em Gênova/Itália, junto ao escritório do Prof. Dr. Victor Uckmar. Professora Universitária, graduada em Direito pela Universidade Estadual de Londrina, Mestre e Doutora em Direito Tributário pela PUC/ SP. Professora orientadora nos cursos de pós-graduação e autora da obra "Direito Tributário" sob coordenação de José Cretella Neto. v. VII, coleção Compacta, ed. Forense, 1997. E-mail: carlabonomo@yahoo.com.br

${ }^{2}$ Bacharel em Direito pela Universidade Estadual de Londrina. Pós-Graduando em Direito Previdenciário pela Universidade Estadual de Londrina. Advogado atuante na Cidade de Londrina - Paraná.
} 


\section{Introdução}

A empresa, a partir do Código Civil de 2002, com vigência a partir do ano de 2003, assumiu papel importante na atual sociedade, por ser um núcleo indispensável da economia de mercado, identificando-se como atividade de natureza precipuamente econômica. Por isso, em respeito à ordem constitucional, ela assumiu um papel social.

Com efeito, a Lei 10.406/2002, efetivou o que já era previsto no artigo $5^{\circ}, \mathrm{XXII}$, da Constituição Federal de 1988, e, ainda, no artigo $170^{3}$ da Constituição Federal.

Por conseguinte, a sociedade empresária, como também é conhecida a empresa, somente existirá em uma sociedade com regime econômico de livre iniciativa e de liberdade de concorrência, porquanto eles indispensáveis a conquista de clientes/consumidores, respeitando os direitos a eles garantidos.

Com efeito, o empresário tem o dever de praticar a atividade econômica organizada de produção e circulação de bens e serviços no mercado consumeirista. Deve respeitar a livre concorrência com a redução das desigualdades sociais, bem como respeitar o meio ambiente e o patrimônio históricocultural, de acordo com a nova ordem social e econômica, e cumprir sua função social.

Dessarte, a empresa inserida no contexto econômico e social vigente, pode atravessar uma crise empresarial. Esse fato dá origem a dificuldades de variadas naturezas, dentre as quais destacam-se a econômica, a financeira e a patrimonial, referentes ao risco empresarial propriamente dito.

Por crise econômica, deve-se entender a retratação dos negócios desenvolvidos pela sociedade empresária, quando os consumidores não mais adquirem igual quantidade dos produtos ou serviços oferecidos, com acentuada queda de faturamento, podendo acontecer, também, com a empresa industrial, fornecedora de insumos, quando são reduzidos os pedidos de outros empresários. Essa crise econômica geralmente ocorre pelo aspecto macroeconômico, como bem sustenta Fabio Ulhôa Coelho (2000).

Dessarte, a empresa assume o risco social que pode ser caracterizado como uma atividade que cria um risco de dano para terceiros e deve ser obrigada à reparação, ainda que sua conduta seja isenta de culpa.

Por esse modo, a Lei 11.101/2005 surgiu para programar mecanismos jurídicos visandoa superação da crise econômico-financeira da empresa com os institutos da recuperação judicial, extrajudicial e falência. Isso trouxe soluções de mercado e novas diretrizes ao regime jurídico brasileiro, em face da crise empresarial, substituindo o antigo instituto da concordata pela recuperação, e alterou as normas referentes à falência, visando a assegurar principalmente a função social da empresa.

Em caso de falência, por completa inviabilidade empresarial, a garantia do cumprimento da obrigação assumida perante os credores é o patrimônio da sociedade empresária em dificuldades (art. 391 C.C.).

Pode-se afirmar que os mecanismos introduzidos com a Lei 11.101/2005, a recuperação judicial, a recuperação extrajudicial e a falência são aptos a assegurar função social às empresas.

\footnotetext{
${ }^{3}$ Art. 170. A ordem econômica, fundada na valorização do trabalho humano e na livre iniciativa, tem por fim assegurar a todos existência digna, conforme os ditames da justiça social, observados os seguintes princípios:

I - soberania nacional;

II - propriedade privada;

III - função social da propriedade;

IV - livre concorrência;

$\mathrm{V}$ - defesa do consumidor;

VI - defesa do meio ambiente, inclusive mediante tratamento diferenciado conforme o impacto ambiental dos produtos e serviços e
} 
Os primeiros porque, como já dito, visam a prestigiar soluções de mercado ao empresário que, juntamente com credores, com ou sem intervenção do Poder Judiciário, vão solucionar as pendências, sem prejuízo da manutenção da empresa, reestruturando-a com melhores alternativas de subsistência, uma verdadeira função social realizada na prática.

E no caso de falência, com o princípio par conditio creditorum, a recente faceta do referido instituto visa a assegurar aos credores tratamento paritário e razoável satisfação de seus créditos, e a empresa irá satisfazer a todos, ou quase a totalidades dos créditos em uma classificação de créditos por suas naturezas.

A sociedade de credores, destacando-se os privilegiados e, mais detidamente, a classe dos trabalhadores, em caso da empresa subsistir, terão seus empregos preservados e, caso contrário, irão receber grande parte de seus pagamentos e respectivas indenizações numa limitação de pagamento de 150 (cento e cinquenta) salários mínimos que será objeto de análise perfunctória em capítulo próprio.

Com efeito, a classificação dos créditos consignada nos artigos 83 e 84 da lei em comento operou grandes avanços no direito falimentar, devendo ser destacados seus aspectos fundamentais neste estudo.

\section{Breve Conceito de Falência}

Inicialmente cumpre destacar o conceito do instituto da Falência, vital para o entendimento posterior da classificação dos créditos. Por conseguinte, verifica-se etimologicamente que o termo falência tem origem no verbo falir, proveniente do verbo latino fallere - faltar, enganar, ou seja, relaciona-se com a falta do cumprimento de uma obrigação ou do que foi prometido (REQUIÃO, 1998, p. 3).

No meio jurídico, ficou patente o entendimento de que a falência expressa a impossibilidade do devedor pagar suas dívidas por insuficiência de patrimônio, ou por não honrar os pagamentos aos credores no prazo estabelecido.

Entretanto, pela influência portuguesa, ficou conhecido o termo "quebra" como sinônimo de falência, com a conceituação de que a quebra poderia ser casual, com culpa ou fraudulenta. (REQUIÃO, 1998, p. 3).

Porém, para se compreender de forma satisfatória o instituto da falência, o pensamento mais moderno se coaduna com o doutrinador Ricardo Negrão, o qual assim dispõe:

A condição da falência refere-se ao não cumprimento das obrigações financeiras por parte do devedor, todavia, nem sempre haverá culpa ou dolo por parte do falido, uma vez que sua situação pode decorrer de diversos fatores econômicos ou mesmo de sua momentânea inabilidade para a prática da atividade empresarial, sem que sua intenção seja fraudar seus credores (NEGRÃO, 2007, p. 6).

Com efeito, fica evidente a caracterização moderna deste instituto, que a partir da legislação de 2005, busca evidenciar um papel social ao estado de falência, resguardando a função social da empresa para a finalidade de se efetuar os pagamentos dos débitos da empresa falida por um critério social e efetivo, pois, ao menos em princípio, esse é o desiderato da lei.

\footnotetext{
de seus processos de elaboração e prestação; (Redação dada pela Emenda Constitucional n 42, de 19.12.2003)

VII - redução das desigualdades regionais e sociais;

VIII - busca do pleno emprego;

$\mathrm{X}$ - tratamento favorecido para as empresas de pequeno porte constituídas sob as leis brasileiras e que tenham sua sede e administração no País. (Redação dada pela Emenda Constitucional nº 6, de 1995)

Parágrafo único. É assegurado a todos o livre exercício de qualquer atividade econômica, independentemente de autorização de órgãos públicos, salvo nos casos previstos em lei.
} 


\section{da Classificação dos Créditos e seu Valor Social - A Função Social}

Antes de debruçar nas características e natureza de cada crédito falimentar, impende (Que tal evitar termos rebuscados? Sugiro um termo mais comum: cabe.) destacar o valor social da ordem de pagamento classificada, a saber:

a) Créditos extraconcursais.

b) Créditos derivados da legislação do trabalho, limitados a 150 salários mínimos por credor, e créditos decorrentes de acidente de trabalho.

c) Créditos com garantia real até o limite do valor do bem gravado.

d) Créditos Tributários, independentemente da sua natureza e tempo de constituição, excetuadas as multas tributárias.

e) Créditos com privilégio especial.

f) Créditos com privilégio geral.

g) Créditos quirografários.

h) Multas contratuais e penas pecuniárias por infração das leis penais ou administrativas, inclusive as multas tributárias.

i) Créditos Subordinados.

Desse modo, a sistemática da Lei 11.101/2005 considerou, como bem sinaliza Gladston Mamede, o interesse público na satisfação dos créditos submetidos à falência definindo a classificação por classes fulcrada na função social da empresa (MAMEDE, 2006).

Nesta toada (O trabalho é de dideito ou de música nordestina? Use: nesse sentido.), embora haja dois credores, p.ex, com os mesmos valores de créditos no importe de R\$30.000.00 (trinta mil reais), se o primeiro provém de legislação do trabalho, ou seja, possuí natureza alimentar, e o segundo provém de uma natureza contratual, no exemplo do contrato de empréstimo celebrado pela sociedade empresária e instituição bancária. Nesse caso, de forma sapiente, o legislador estabeleceu que o credor de crédito de natureza trabalhista receberá o valor acima referido, enquanto o segundo, por ser de natureza contratual, receberá depois de todos os demais credores por não haver nenhuma preferência em seu recebimento, por ser crédito de natureza quirografária. Esse exemplo torna prático o entendimento do interesse social na falência e evidencia, de forma clara, 0 atendimento à função social da empresa.

Por outras palavras, a lei de falência trouxe um paradigma importante, transformando o par conditio creditorum em praeferentia creditorum in concurso. Trata-se de algo que advém da ordem social, posto que seria injusto que um grande credor bancário recebesse antes de um trabalhador que despendeu anos de labuta com muito empenho e sacrifício, o que torna cogente a satisfação do crédito trabalhista - alimentar.

Entretanto, será que o legislador cumpriu exatamente o anseio social neste novo paradigma de classificação? Ou em alguns créditos aconteceu retrocesso? Será que o limite de 150 (cento e cinquenta) salários mínimos por trabalhador cumpre a função social da empresa?

Eis, algumas questões, para as quais se buscará uma explicação, com a finalidade de ser comprovada a função social da empresa na classificação dos créditos falimentares.

\section{dos Créditos em Espécie - Créditos Extraconcursais}

É cediço (juridiquês...) que a massa falida, depois da decretação da falência ou durante a recuperação judicial, tenha que arcar com despesas com pessoal, entre outras, como sabiamente ressalta Mamede, “que não se está, portanto, diante de uma situação de preferência, mas de uma situação de prejudicialidade: antes aos credores do devedor, é preciso reconhecer a existência de credores da massa falida." (MAMEDE, 2006, p. 593), nos 
termos do art. $84^{4}$ da Lei de Falências.

Não bastasse isso, a legislação de 2005 buscou resguardar outros credores como mencionado no artigo acima referido, no que tange aos que promoveram a ação de falência, conforme preconiza o inciso IV, que resguarda o pagamento desses créditos oriundos da ação judicial e suas custas devidas, um entendimento correto por questão de justiça. Ressalte-se o entendimento do Ministro Eduardo Ribeiro, que conspicuamente (Juridiquês) asseverou no Recurso Especial 32.959/SP:

Em um processo de falência, notadamente a realização do ativo, não se faz sem despesas. É não é razoável pretender que alguém contrate com a massa sem uma certa segurança de que irá receber o que lhe é devido. Daí a conveniência de que os débitos com essa origem sejam saldados preferencialmente, evitando-se óbices ao desenvolvimento do processo, sem o que não será possível o pagamento dos créditos admitidos à falência, inclusive trabalhistas (BRASIL, 1997).

Como estabelecido acima, esses créditos, para subsistência da massa, são imprescindíveis, tanto na falência quanto na recuperação judicial, pois assegura uma preferência aos credores, entre os quais administrador judicial e de sua equipe de trabalho, pois desempenham um verdadeiro múnus público, recebendo seus créditos como um incentivo ao trabalho em prol da massa falida. Com efeito, pela legislação anterior, recebiam após os credores trabalhistas e por acidente de trabalho, nos moldes do no art. $124^{5}$ do Decreto Lei 7.661/1995. Por esse modo, como bem assevera Rubens Approbato: "Note-se ainda que, na realidade, os créditos ora denominados extraconcursais eram, na vigência do Decreto Lei $\mathrm{n}^{\mathrm{o}} 7.661 / 45$, os chamados encargos da massa, e hoje preferem a todos os demais créditos e devem ser pagos antes de qualquer credor incluído na classificação do artigo 83" (APPROBATO, 2006, p. 251).

Por conseguinte, o legislador nada mais fez que ratificar o entendimento justo quanto à preferência dos créditos extraconcursais na falência, e mais, inseriu um superprivilégio a este crédito, por ser recebido antes dos créditos trabalhistas, que pela legislação anterior detinham a condição de preferência absoluta.

\section{Dos créditos trabalhistas e acidentários}

O legislador estabeleceu, pelo art. 83 da Lei de Falência, a primazia dos créditos trabalhistas e por acidente de trabalho. Desta feita, com a arrecadação e a formação do concurso de credores, os trabalhadores receberão seus créditos antes dos demais, salvo a natureza dos créditos extraconcursais, pois estes preferem a todos os créditos, como acima se viu.

A legislação falimentar há tempos deveria modernizar-se e trouxe as alterações devidas com a Lei 11.101/2005.

Desse modo, a referida lei regula de modo mais claro as regras para efetivar os direitos de todos os credores, assim como, efetiva claramente as regras dos direitos aos trabalhadores, no entendimento do relator da lei em apreço, senador Ramez Tebet, in memorian.

\footnotetext{
${ }^{4}$ Art. 84. Serão considerados créditos extraconcursais e serão pagos com precedência sobre os mencionados no art. 83 desta Lei, na ordem a seguir, os relativos a:

I - remunerações devidas ao administrador judicial e seus auxiliares, e créditos derivados da legislação do trabalho ou decorrentes de acidentes de trabalho relativos a serviços prestados após a decretação da falência;

II - quantias fornecidas à massa pelos credores;

III - despesas com arrecadação, administração, realização do ativo e distribuição do seu produto, bem como custas do processo de falência;

IV - custas judiciais relativas às ações e execuções em que a massa falida tenha sido vencida;

$\mathrm{V}$ - obrigações resultantes de atos jurídicos válidos praticados durante a recuperação judicial, nos termos do art. 67 desta Lei, ou após a decretação da falência, e tributos relativos a fatos geradores ocorridos após a decretação da falência, respeitada a ordem estabelecida no art. 83 desta Lei.

${ }^{5}$ Art. 124. Os encargos e dívidas da massa são pagos com preferência sobre os créditos admitidos à falência, ressalvado o disposto nos arts. 102 e 125.

$\S 1^{\circ}$ São encargos da massa:
} 
Entretanto, antes de pormenorizar as características dos créditos trabalhistas, realce-se a competência do juízo falimentar quanto ao procedimento do pagamento dos créditos trabalhistas. Ao final da liquidação do processo trabalhista, deve ser expedido o valor apurado, para habilitação no rol de credores da massa falida, no Juízo Universal, nos termos do art. $6^{\circ}, \S 2^{\mathrm{o} 6}$ da Lei $11.101 / 2005$.

Ainda sobre o critério básico de pagamento dos créditos trabalhistas, urge destacar que os créditos oriundos dos honorários advocatícios contratados são equiparados aos créditos trabalhistas, pelo fato de possuírem natureza alimentar, bem como são considerados equiparados aos créditos trabalhistas os oriundos do labor pelo representante comercial, por interpretação extensiva consubstanciada no art. $44^{7}$ da Lei 4.886/65, dando, desse modo, cumprimento à função social da empresa. $\mathrm{O}$ critério de pagamento será aprofundado no próximo capítulo.

Dos critérios de pagamento dos créditos trabalhistas e acidentários pela lei 11.101/2005

A classificação dos créditos, no que tange os créditos trabalhistas. está configurada no art. $83, \mathrm{I}^{8}$, da Lei 11.101/2005.
Desta feita, ao observar o dispositivo legal, infere-se a característica social dos créditos trabalhistas, pois eles têm preferência acima todos os demais créditos falimentares, com exceção dos créditos extraconcursais, como estudado no capítulo anterior.

Pelo Decreto-Lei 7661/1945, os créditos trabalhistas obedeciam ao critério consignado no art. $102^{9}$, podendo se inferir que os créditos em comento tinham privilégio maior pela antiga legislação, ou seja, tinham uma prioridade absoluta sobre todos os créditos falimentares.

Tanto é verdade que Rubens Requião indica que a partir do Decreto-Lei $n^{\circ} 192 / 1967$, os créditos trabalhistas alçaram um superprivilégio, tendo preferência sobre todos os demais créditos, inclusive, naquele momento, sobre os créditos tributários, cedendo prioridade somente para os créditos por acidente de trabalho (REQUIÃO, 1998).

Realce que pela Lei 11.101/2005, os créditos por acidente de trabalho receberam tratamento especial e melhoraram substancialmente sua posição na classificação geral, porquanto, no sistema anterior, figuravam após os créditos tributários.

I - as custas judiciais do processo da falência, dos seus incidentes e das ações em que a massa for vencida;

II - as quantias fornecidas à massa pelo síndico ou pelos credores;

III - as despesas com a arrecadação, administração, realização de ativo e distribuição do seu produto, inclusive a comissão do síndico;

IV - as despesas com a moléstia e o enterro do falido, que morrer na indigência, no curso do processo;

$\mathrm{V}$ - os impostos e contribuições públicas a cargo da massa e exigíveis durante a falência;

VI - as indenizações por acidente do trabalho que, no caso de continuação de negócio do falido, se tenha verificado nesse período.

${ }^{6}$ Art. 60 A decretação da falência ou o deferimento do processamento da recuperação judicial suspende o curso da prescrição e de todas as ações e execuções em face do devedor, inclusive aquelas dos credores particulares do sócio solidário.

§ 20 É permitido pleitear, perante o administrador judicial, habilitação, exclusão ou modificação de créditos derivados da relação de trabalho, mas as ações de natureza trabalhista, inclusive as impugnações a que se refere o art. 8o desta Lei, serão processadas perante a justiça especializada até a apuração do respectivo crédito, que será inscrito no quadro-geral de credores pelo valor determinado em sentença.

${ }^{7}$ Art.44. No caso de falência do representado as importâncias por ele devidas ao representante comercial, relacionadas com a representação, inclusive comissões vencidas e vincendas, indenização e Aviso Prévio, serão considerados créditos da mesma natureza dos créditos trabalhistas.

${ }^{8}$ Art. 83. A classificação dos créditos na falência obedece à seguinte ordem:

I - os créditos derivados da legislação do trabalho, limitados a 150 (cento e cinqüenta) salários-mínimos por credor, e os decorrentes de acidentes de trabalho;

${ }^{9}$ Art. 102. Ressalvada a partir de 2 de janeiro de 1958, a preferência dos créditos dos empregados, por salários e indenizações trabalhistas, sôbre cuja legitimidade não haja dúvida, ou quando houver, em conformidade com a decisão que fôr proferida na Justiça do Trabalho (grifo nosso), e, depois dêles a preferência dos credores por encargos ou dívidas da massa (art. 124), a classificação dos créditos, na falência, obedece à seguinte ordem: (Redação dada pela Lei no 3.726, de 11.2.1960) (BRASIL, 1960). 
Logo, a partir da Lei 11.101/2005, o crédito por acidente de trabalho assim ficou definido: se a indenização acidentária provier de serviço prestado após a decretação da falência, o crédito é extraconcursal (art. 84, I); se anterior à quebra, o crédito é privilegiado e concorre com o decorrente da legislação trabalhista no mesmo rateio.

Entretanto, cabe esclarecer que o crédito acidentário não obedece a nenhuma limitação, tendo com isso um privilégio maior sobre os trabalhistas, pois estes sofrem a limitação do pagamento até 150 (cento e cinqüenta) salários mínimos por credor, vez que é comum que os trabalhadores sofram as conseqüências imediatas do acidente de trabalho, algumas vezes perdendo a própria vida, com sequelas que afetam diretamente a família do obreiro, denotando claro atendimento à função social da empresa.

Com efeito, a lei de falência buscou trazer a primazia aos créditos acidentários e relegou a primazia dos créditos propriamente ditos trabalhistas, aspecto que precisará ser abordado de forma especial, tendo em vista a limitação no recebimento dos créditos já comentada, e que será, doravante, apresentada com as devidas ponderações.

Análise dos créditos trabalhistas quanto a limitação ao pagamento até cento e cinquenta salários mínimos

Um ponto de destaque na lei 11.101/2005 que impera em relação aos créditos trabalhistas é que não mais gozam de grau de preferência absoluta no concurso falimentar, diante do limite estabelecido por lei em até 150 (cento e cinquenta) salários mínimos.

Desse modo, aquele trabalhador que possui créditos nos valores maiores que do teto de 150 (cento e cinquenta) salários mínimos, participa do concurso em duas classes: pelo valor de 150 (cento e cinqüenta) salários mínimos, na classe dos empregados e equiparados; e pelo que exceder, na classe dos credores quirografários, o que, na realidade, consiste em dizer que provavelmente não receberá seus créditos, sendo que, na visão de Newton de Lucca, o referido dispositivo legal revela-se um tanto omisso em relação à forma pela qual se dará o rateio quirografário (LUCCA, 2005).

Por sua vez, Fabio Ulhoa Coelho assevera que essa limitação tem como objetivo impedir que se consumam os recursos da massa com o atendimento a altos salários dos administradores da sociedade falida, atendendo, desta feita, os mais necessitados (COELHO, 2008, p. 215), cumprindo sua função social.

Porém, o nobre doutrinador Sérgio Campinho entende de forma diversa, pois assim assinala:

O intento da Lei foi o de não atender com preferência absoluta àqueles créditos provenientes de alto salário detidos por administradores ou empregados graduados. A perspectiva não nos pareceu irradiadora de equidade, eis que créditos trabalhistas também o são. O empregado que ganha muito ou pouco, não importa, deve ser considerado como empregado. Os direitos sociais a serem atendidos têm tronco comum. Eventual fraude verificada, por exemplo, com a elevação artificial de salários de pessoas ligadas aos controladores da sociedade, expediente engendrado com o fim de retirar valores da massa, dada a prioridade no pagamento dentro do concurso falimentar, deveria ser atacada por remédios próprios [...]. Há, para nós, um equívoco. A fraude não se presume. Deve ser comprovada. São os probos punidos, porque o legislador constrói um sistema defensivo, que inverte conceitos. Parte da presunção de que quem aufere um bom salário não deve ser com preferência atendido, porque o fato poderia revelar manobra capaz de subtrair recursos da massa, destinados ao pagamento de outros credores. Isso nos parece um absurdo (CAMPINHO, 2008, p. 406-407).

No pensamento de Sérgio Pinto Martins, aliás, e, também polêmico, assim se compreende:

[...] mesmo o trabalhador que ganha salário mais elevado, não sendo exatamente hipossuficiente, deve receber a totalidade dos seus créditos decorrentes do seu suor, pois este trabalhador e sua família também vivem do que a empresa lhe paga. [...] Se existem fraudes no recebimento de verbas trabalhistas elevadas na falência, por pessoas que sequer são empregados e acabam tendo preferências sobre outros créditos trabalhistas, elas devem ser combatidas. O Ministério Público vem ajuizando ações rescisórias contra pessoas que não são empregados e que pretendiam receber créditos fraudulentos nas falências, obtendo excelentes resultados. [...] A exceção não pode ser tomada como regra. A fraude não pode ser presumida 
sempre, mas, ao contrário, deve ser provada. A boafé se presume e não o contrário. Deve ser observado o interesse público e da coletividade em relação ao interesse particular, especialmente de créditos bancários (MARTINS, 2007, p. 11.).

Não obstante os pensamentos dos insignes doutrinadores acima, o professor Gladston Mamed fundamenta que a limitação dos créditos não é inconstitucional, porém, estabelece de forma conspícua uma crítica ao sistema, que merece ser destacada:

Neste embate, confesso-me, em primeiro lugar, um crítico da fixação do limite para o gozo da preferência em meros 150 salários mínimos, mormente considerando os valores que atualmente são pagos a este título, mesmo após a longa duração de um governo que se intitulava social-democrata e, pior, de outro governo, que se intitulava socialista. Não me passa despercebido que a média de vencimentos do brasileiro não alcança três salários mínimos e, apenas com muito esforço, chegaria a quatro. Isto, porém, é uma vergonha nacional, deixando claro que não nos libertamos de uma lógica de exploração de seres humanos, cujo trabalho é desvalorizado pelo salário. Apesar de todo o esforço de modernização do país, esse limite simplesmente fecha os olhos para o trabalhador qualificado, cuja remuneração - e, mais, os gastos familiares - superam quatro salários mínimos mensais. No entanto, não me parece que desse absurdo decorra inconstitucionalidade. Se houvesse, seria, antes, a inconstitucionalidade do próprio valor do trabalho (artigo $1^{\circ}$, IV, da Constituição). O limite apenas traduz um padrão, uma parâmetro, permitindo, assim, atender a outros princípios jurídicos: o próprio artigo $1^{\circ}$, IV, da Constituição da República, quando fala no valor da livre iniciativa; ambos são, dialeticamente, princípios jurídicos fundamentais que norteiam o Estado Democrático de Direito. Poderse-ia falar, ademais, em diversos outros princípios jurídicos, como o da isonomia (artigo $5^{\circ}$, caput, da Constituição), da propriedade (artigo $5^{\circ}$, XXII, e 170, II, da Constituição), que igualmente se colocam como sustentação para uma limitação da proteção ao credor trabalhista, em nome da proteção aos demais credores. Foi o que se fez (MAMEDE, 2006, p. 570).

Portanto, cediço é (Juridiquês) que os créditos trabalhistas possuem o privilégio já demonstrado, porém, muita controvérsia se viu sobre a limitação, algumas até acaloradas, como se percebe na posição do eminente jurista e Magistrado Sérgio Pinto Martins. Todavia, o Supremo Tribunal Federal já decidiu pela constitucionalidade da limitação em comento, no julgamento da Ação Direta de
Inconstitucionalidade de $\mathrm{n}^{\mathrm{o}} 3.934 \mathrm{DF}$, que foi proposta pelo Partido Democrático Trabalhista PDT, bem como está tramitando, também, no STF, a Ação Direta de Inconstitucionalidade de $n^{0} 3.424$ DF, que foi ajuizada pela Confederação Nacional das Profissões Liberais (CNPL), e que teve como última decisão, em 08/11/2011, a inclusão do Instituto Brasileiro de Estudos de Recuperação de Empresas - IBR, na qualidade de amicus curiae. Essas ações merecem atenção especial, tendo em vista que buscam retirar da Lei 11.101/2005 as limitações dos créditos dos trabalhadores, como será doravante estudado.

Da limitação ao pagamento de até cento e cinquenta salários mínimos dos créditos trabalhistas e sua constitucionalidade decidida pelo Supremo Tribunal Federal

Como mencionado, o legislador da Lei 11.101/2005 buscou limitar o pagamento dos créditos trabalhistas em até 150 salários mínimos, com o intuito de resguardar o pagamento da classe de trabalhadores que, em média, não recebiam mais do que dois salários mínimos como forma de remuneração, bem como colocaria em segundo plano, profissionais de altos cargos na empresa, cujo crédito poderia prejudicar o recebimento da maioria, vez que cento e cinquenta salários mínimos equivalem atualmente ao importe de $\mathrm{R} \$ 93.300,00$ (noventa e três mil e trezentos e cinquenta reais), valor altamente discutido por juristas, devido à evolução ínfima do Salário Mínimo ${ }^{10}$.

O Relator do projeto PCL no 71/2003, Senador Ramez Tebet, assim expôs sobre a limitação em cotejo:

O objetivo da limitação à preferência do crédito trabalhista é evitar abuso freqüente no processo falimentar, pelo qual os administradores das sociedades falidas grandes responsáveis pela derrocada do empreendimento, pleiteiam por meio de ações judiciais milionárias e muitas vezes frívolas, em que a massa falida sucumbe em razão da falta de interesse em uma defesa eficiente $-\mathrm{o}$ recebimento de altos valores, com preferência sobre todos os outros credores e prejuízo aos ex-empregados que efetivamente deveriam ser protegidos, submetendo-os a rateios com os ex- 
ocupantes de altos cargos. Tal modificação, longe de piorar a situação dos trabalhadores, garante a eles maior chance de recebimento, pois reduz-se a possibilidade de verem parte significativa do valor que deveriam receber destinada ao pagamento dos altos valores dos quais os ex-administradores afirmam ser credores trabalhistas. No Senado Federal, porém, a questão foi finalmente esclarecida e, na audiência pública realizada nesta Comissão de Assuntos Econômicos em 5 de fevereiro de 2004, as duas maiores centrais sindicais brasileiras pronunciaram seu apoio à criação de um limite à preferência do crédito trabalhista. Propomos, portanto, a criação de um limite à preferência do crédito trabalhista de 150 salários mínimos por trabalhador. $\mathrm{O}$ valor que superar o limite deverá ser inscrito no quadro geral como crédito quirografário. Ressalta-se, para que não restem dúvidas, que não haverá limite para a preferência do crédito decorrente de acidente de trabalho, haja vista a baixa probabilidade de que sirva de fraude de ex-administradores. Segundo os dados mais recentes do Tribunal Superior do Trabalho, o número de julgados e conciliações na Justiça do Trabalho no ano de 2002 foi de aproximadamente 4 bilhões de reais. Desse modo, a média dos valores pagos na Justiça do Trabalho foi próxima de $\mathrm{R} \$$ 200,00 vigente à época, as indenizações, em média, foram de 12 salários mínimos (hoje equivalente a R\$ 36 mil) afetará número reduzidíssimo de assalariados, entre os quais estarão, exclusivas ou primordialmente, os ocupantes de cargos elevados na hierarquia das sociedades (BRASIL, 2003 ).

Todavia, Sérgio Pinto Martins, mais uma vez, teceu várias críticas, entre as quais, destaca-se abaixo um trecho:

Justifica-se a preferência do crédito trabalhista em
razão da natureza que tem, pois na grande maioria
das vezes o empregado e sua família dependem
exclusivamente do recebimento das verbas decorrentes
do contrato de trabalho para poder sobreviver, Isso
também tem característica social, pois o empregado
paga seus compromissos com tais créditos e
impulsiona a economia. Se o empregado deixar de
receber, outras pessoas também podem deixar de
receber seus créditos do obreiro, que não terá como
pagar suas dívidas. Por isso, o crédito trabalhista deve
ser protegido. Indenização de muitos anos de casa
pode ser superior ao teto proposto. Basta a empresa
não ter recolhido o FGTS por um bom período.
Somada com as verbas rescisórias ou outros haveres,
como horas extras, o trabalhador simplesmente recebe
o teto e o restante fica a ver navios, porque na maioria
das vezes não há bens a serem vendidos para saldar a
dívida da massa (MARTINS, 2007, p. 10).
Com efeito, há posições contrárias ou favoráveis à limitação. Ora, o direito é interpretativo, e o controle de constitucionalidade é exercido pelo Supremo Tribunal Federal para estabelecer os parâmetros constitucionais das leis, o Partido Democrático Trabalhista - PDT ingressou no ano de 2004 com Ação Direta de Inconstitucionalidade n.3.934 DF, requerendo a Inconstitucionalidade do artigo 83, IV e VI da Lei de Falência, com fundamento da limitação do exercício dos direitos trabalhistas pelos dispositivo do artigo 83 da LRF, que confronta com as garantias do direito adquirido, da isonomia e as garantias dos direitos sociais do trabalho e do emprego.

Dentro desses aspectos, o partido requerente fundamentou que a classificação dos créditos trabalhistas como quirografários, caso ultrapassassem o limite de 150 salários mínimos seria inconstitucional, por passar a constituir caminho fácil para o desrespeito aos direitos adquiridos pelos empregados no curso da relação desenvolvida com seu empregador, que vindo a prestigiar outros credores comuns e, uma vez acumulando com eles grandes dívidas, delas se poderiam se livrar com a simples realização de uma alienação judicial em falência.

Ainda almejou a inconstitucionalidade do artigo 83, nos incisos já mencionados, fundamentando que o artigo $1^{\circ}$, IV da Carta Magna homenageia o valor social do trabalho no inciso IV, bem como pelo artigo $6^{\circ}$, o trabalho é qualificado como direito social, ao lado da educação, saúde, moradia, lazer, segurança, previdência social.

Ainda o artigo 170 da Lei Maior estabeleceu que o dispositivo, ao tratar da ordem econômica, não deixa de erigir a valorização do trabalho humano como seu primeiro pilar, erigindo na função social também da empresa, junto com o artigo 193 da Carta Magna.

\footnotetext{
${ }^{10}$ Tabela de evolução do Salário Mínimo:

01/01/2012/ R\$ 622,00; 01.03.2011/ R\$ 545,00; 01.01.2010/ R\$ 510,00; 01.02.2009/ R\$ 465,00; 01.03.2008/ R\$ 415,00; 01.04.2007/R R 380,00; 01.04.2006/R \$ 350,00; 01.05.2005/ R\$ 300,00
} 
Defendeu também que a vinculação do referido limite a 150 salários mínimos foi feita para restringir os exercícios dos direitos trabalhistas, e não é razoável admitir que a regra estabelecida em rol taxativo de direitos assegurados aos trabalhadores, contida no inciso IV do artigo $7^{\circ}$ da Carta Magna viesse a ser utilizada, justamente para cercear ou limitar o exercício de direito dessa natureza.

Por derradeiro, alinhavou que não houve por parte do legislador constituinte, no estabelecimento dos princípios gerais da Carta da República, neles incluídos os direitos e garantias sociais do trabalho, qualquer ressalva quanto à possibilidade de lei ordinária vir a cercear ou limitar os exercícios dos direitos trabalhistas, como é o caso apontado no I do artigo 83 da Lei 11.101/2005. Esse artigo só reconhece como sendo crédito preferencial de natureza trabalhista as importâncias que forem iguais ou inferiores a 150 salários mínimos, o que macula de inconstitucionalidade a limitação em estudo.

Com todos os elementos suficientes, o Supremo Tribunal Federal julgou, pelo Tribunal Pleno, a improcedência da Ação Direta de Inconstitucionalidade de $n^{\circ} 3934$, com os votos vencidos dos senhores Ministros Carlos Britto e Marco Aurélio em 27 de maio de $2009^{11}$.

Nos votos, cabe realçar o posicionamento do Relator Ministro Ricardo Lewandowski, no sentido de que na visão dele não há qualquer perda de direitos por parte dos trabalhadores, vez que, independente da categoria em que esses créditos estejam classificados, eles não deixam de existir nem se tornam inexigíveis, não desaparecem pelos simples fato de serem convertidos em quirografários, mas apenas perdem seu caráter preferencial, não ocorrendo, por este aspecto qualquer inconstitucionalidade.

Ainda destacou que a própria legislação internacional de proteção ao trabalhador contempla a possibilidade do estabelecimento de limites legais aos créditos de natureza trabalhista, desde que alberguem a sobrevivência do empregado, com base na Convenção 173 da Organização Internacional do Trabalho, Convenção sobre Proteção dos Créditos Trabalhistas em Caso de Insolvência do Empregador. No art. 7.1, a Convenção dispõe que "a legislação nacional poderá limitar o alcance do privilégio do crédito trabalhista a um montante estabelecido, que não deverá ser inferior a um mínimo socialmente aceitável."

Dentre os dois votos favoráveis a ADIN em destaque, o Ministro Carlos Britto fundamentou que a preferência estabelecida em favor dos créditos derivados da relação de trabalho é absolutamente inconstitucional, tendo em vista que esta primazia resulta de diversos dispositivos constitucionais, entre os quais o artigo 193 da Carta Magna ${ }^{12}$, e tal limitação seria eivada de inconstitucionalidade, bem como o Senhor Ministro Marco Aurélio votou pela inconstitucionalidade do art. 83, I, ressaltando que a Lei Maior deixa claro que é proibida a indexação de valores em salários mínimos, limitando os valores que os trabalhadores teriam direito a receber.

Não obstante a ADIN 3.934 ter sido julgada improcedente, a Confederação Nacional das Profissões Liberais (CNPL) ajuizou a Ação Direta de Inconstitucionalidade $\mathrm{n}^{\mathrm{o}} 3.424 \mathrm{DF}$ em $04 / 05 / 2005$,

${ }^{11}$ DIRETA DE INCONSTITUCIONALIDADE. ARTIGOS 60, PARÁGRAFO ÚNICO, 83, I E IV, c, E 141, II, DA LEI 11.101/2005. FALÊNCIA E RECUPERAÇÃO JUDICIAL. INEXISTÊNCIA DE OFENSA AOS ARTIGOS $1^{\circ}$, III E IV, $6^{\circ}, 7^{\circ}$, I, E 170, DA CONSTITUIÇÃO FEDERAL de 1988. ADI JULGADA IMPROCEDENTE. I - Inexiste reserva constitucional de lei complementar para a execução dos créditos trabalhistas decorrente de falência ou recuperação judicial. II - Não há, também, inconstitucionalidade quanto à ausência de sucessão de créditos trabalhistas. III - Igualmente não existe ofensa à Constituição no tocante ao limite de conversão de créditos trabalhistas em quirografários. IV - Diploma legal que objetiva prestigiar a função social da empresa e assegurar, tanto quanto possível, a preservação dos postos de trabalho. V - Ação direta julgada improcedente. (BRASIL. Supremo Tribunal Federal. ADI 3934, Relator(a): Min. RICARDO LEWANDOWSKI, Tribunal Pleno, julgado em 27/05/2009, DJe-208 DIVULG 05-11-2009 PUBLIC 06-11-2009 EMENT VOL-02381-02 PP-00374). 
na qual pugnou pela inconstitucionalidade do art. 83 da Lei 11.101/2005 nos incisos "I" e "V" letra "c", alegando que a limitação a cento e cinquenta salários mínimos afetaria categoria de profissionais diferenciada e, a lei 11.101/2005 traria consequências nefastas a princípios tutelados pela Constituição Federal, ferindo os artigos $6^{\circ}, 7^{\circ}$ no inciso $\mathrm{X}$, artigo 170, III , artigo 193. Este artigo prima pela ordem social com base no primado do trabalho e justiças sociais, bem como tal limitação feriria a soberania e integridade do texto constitucional, vez que os profissionais liberais não receberiam seus créditos integralmente.

A requerente sustentou também que a classe média, integrada, em grande parte, por profissionais liberais, já é atingida naquilo que lhe é mais caro, precioso e imprescindível - a contrapartida de seu trabalho qualificado, e que trabalhadores mais qualificados, depois dos quarenta anos de idade, raramente encontram novo espaço no mercado de trabalho, e a indenização trabalhista, muitas vezes, serve para constituição de pequenos negócios ou para formação de pequenas poupanças a minorar as agruras do tempo outonal da existência, ferindo também o princípio da isonomia, presente na Carta Magna.

Embora a tese da Confederação Nacional das Profissões Liberais, em síntese, seja alicerçada em forte suporte constitucional, é bem provável que essa ação seja julgada improcedente, pois como já amplamente abordado, exatamente na tese do Supremo Tribunal Federal, quando julgou a ADIN 3.934, alinhavou-se no sentido exato de que este seria o escopo do legislador na criação da limitação, garantir isonomia entre os trabalhadores, com o recebimento dos créditos por todos os obreiros, ratificando que limitação protegeria, e não feriria direitos, como já exposto, e certamente será o mesmo posicionamento do Supremo no julgamento da ADIN sob análise, que ainda não foi julgada.
Por esse modo, a limitação ao recebimento dos créditos trabalhistas em cento e cinquenta salários mínimos pode ser interpretada como constitucional, cumprindo efetivamente a função social da empresa na falência, pois assegura o pagamento de créditos aos trabalhadores, e confere a possibilidade de que os demais credores também recebam seus créditos, e mantém incólumes os princípios falitários, máxime a par (?) conditio creditorium, correspondente aos princípios constitucionais da isonomia e da igualdade, e, assim, a empresa possa saldar em grande parte seu passivo.

\section{Dos créditos com garantia real}

Inicialmente, importa ressaltar que é comum no direito comercial, a empresa, com o fito de obtenção de crédito e bens, operar negócios com instituições bancárias, por meio de contratos cujo objeto é a garantia real do bem.

Conforme dispõe o art. 1.419 do Novo Código Civil, "nas dívidas garantidas por penhor, anticrese ou hipoteca, o bem dado em garantia fica sujeito, por vínculo real, ao cumprimento da obrigação".

Com efeito, as garantias são vinculadas aos bens sobre os quais incidem, assegurando ao titular o poder de exercitá-la, expropriando o bem e satisfazendo-se com o preço apurado na venda, ainda que a propriedade dos bens tenha sido transferida a outrem.

A bem da verdade, na falência, esses créditos são oriundos das dívidas garantidas por penhor, anticrese ou hipoteca, sendo que o bem dado em garantia fica sujeito, por vínculo real, ao cumprimento da obrigação até o limite do valor do bem gravado.

Outrossim, é admitida em doutrina a alienação fiduciária como crédito com garantia real.

Com bem expõe Gladston Mamede, "essa conexão entre o direito obrigacional e o direito real não encontra limitação qualitativa alguma, ou seja,

\footnotetext{
${ }^{12}$ Art. 193. A ordem social tem como base o primado do trabalho, e como objetivo o bem-estar e a justiça sociais.
} 
não há vedação constitucional ou legal para que obrigações com tal ou qual conteúdo ou qualidade não possam ser garantidas por penhor, anticrese ou hipoteca" (MAMEDE, 2006, p. 582).

Todavia, deve estar em harmonia com o artigo 83, II, da Lei 11.101/2005, tanto que o legislador pretendeu reconhecer que a natureza desses créditos atende de tal forma ao interesse público, que, em relação a eles, excepciona-se a regra da especialização patrimonial da garantia e do vínculo real que marca a relação obrigacional.

Para haver sintonia ao cumprimento do pagamento dos créditos no esteio do artigo 83 da lei em estudo, depois do pagamento dos créditos extraconcursais, acidentários e trabalhistas, havendo mais de um credor com direito real de garantia, cada um receberá o produto da venda do bem gravado até o limite de seu crédito.

Se o bem gravado for insuficiente, o saldo é admitido como quirografário e se, ao contrário, o crédito é inferior ao valor alcançado pelo bem, o saldo é lançado para o rateio da próxima classe, a dos créditos tributários, tendo em vista que não há comunicação entre bens e credores com garantia real.

Outra questão de ordem prática em relação ao pagamento dos créditos com garantia real ocorre quando os recursos da massa são insuficientes para os pagamentos dos créditos extraconcursais e dos de natureza trabalhista, que de forma didática explana Sérgio Campinho:,

Suponha-se que sejam necessários cinqüenta mil reais para a satisfação integral dos créditos na natureza trabalhista, não havendo outros bens a liquidar senão aqueles objeto da garantia real, nem outra fonte de recursos. Existindo cinco credores com garantia real, titularizando cada um crédito no valor de cento e vinte mil reais, e apurando-se, em cada uma das vendas dos bens gravados, cem mil reais, perfazendo o total de quinhentos mil reais, cada credor perderá na satisfação do seu crédito a importância de dez mil reais, vertendo-se, assim, os cinquenta mil necessários à integral satisfação dos créditos que os preferem. Com a providência, estar-se-á garantindo a efetividade da ordem de classificação dos créditos, sem prejudicar o tratamento igualitário que se deve dispensar aos credores de uma mesma classe, ainda que entre eles não se faça o rateio. Não se pode admitir nem a falta de satisfação do crédito com recebimento priorizado, nem que o respectivo ônus recaia somente sobre um credor com garantia real (CAMPINHO, 2008, p. 411).

Não obstante as considerações abordadas acima, uma das grandes polêmicas surgidas pela classificação creditícia apontada pela Lei de Falência de 2005, revela-se na preferência desses créditos antes dos créditos tributários, tendo em vista que alcançaram o segundo posto na classificação geral, porquanto, outrora, estavam em ordem de recebimento depois dos créditos fiscais, enfartizando também, neste caso, cumprimento à função social da empresa.

Para fundamentação da preferência consignada na LRF, o Senador Ramez Tebet, explanou que havia a necessidade da legislação consignar a redução dos custos do crédito no Brasil e conferir segurança jurídica aos detentores do capital, com a preservação das garantias e normas precisas sobre a ordem de classificação de créditos na falência com a finalidade de incentivar a aplicação de recursos financeiros a custo menor nas atividades produtivas, com objetivo de estimular o crescimento econômico. Com isso concede-se a preferência necessária aos pagamentos dos créditos com garantia real (BRASIL, 2003).

Com efeito, pode-se inferir que o escopo do legislador em ressalvar a preferência do pagamento dos créditos com garantia real, antes dos tributários, foi fomentar a economia, garantindo aos credores destes créditos a segurança na elaboração de contratos com a empresa, antes da falência, tendo em vista que, pelo Decreto 7.661/1945 os bancos credores, muitas vezes, não recebiam seus créditos.

Não obstante, críticas severas surgiram à preferência em análise com as alegações de que tal preferência seria um lobby político das instituições bancárias, junto ao legislador da LRF, porém, essas assertivas serão objeto de destaque no capítulo posterior, na abordagem dos créditos tributários, em tese, prejudicados pelo novo paradigma na 
classificação dos créditos falimentares.

\section{Dos créditos tributários}

Inicialmente é de se destacar o conceito do crédito tributário que é a quantia devida a título de tributo, e objeto a obrigação jurídica tributária, como consignado no art. $139^{13}$, do CTN.

Outrossim, é de conhecimento comum que a administração pública, para manutenção da máquina e a cobertura de todas as despesas sociais, necessita da arrecadação dos tributos para cumprimento do ônus público, que se resume no interesse social.

No direito falencial, não poderia ser diferente a questão da cobrança do crédito tributário, e a preferência que legislador deu a estes créditos se definem na letra do dispositivo, não havendo diferenças entre os tributos federais, estaduais, distritais ou municipais, no que tange ao recebimento na ordem de credores, excluindo-se do recebimento as multas, pois esses créditos são recebidos depois dos créditos quirografários.

Realce que, na legislação anterior, o crédito tributário tinha uma preferência absoluta sobre os demais créditos, salvo o privilégio dos créditos trabalhistas, acidentários e encargos da massa (extraconcursais), de acordo com o artigo $186^{14}$ do Código Tributário Nacional.

De fato, este era o entendimento jurisprudencial e doutrinário, pois assim defendia o insigne Aliomar Baleeiro: “o privilégio do crédito tributário pode ser considerado absoluto, pois deverá ser pago de preferência a qualquer outro, exceto os decorrentes de legislação do trabalho, isto é, salários e indenizações, incluindo-se nestas, a nosso ver, para esse fim, também as indenizações da Lei de Acidentes do Trabalho" (BALEEIRO, 1991, p. 606).
Todavia, o legislador, como já disposto, retirou a preferência absoluta desses créditos, com o escopo de garantir a fomentação da economia. Comso concedendo a preferência dos créditos com garantia real, sobre os créditos tributários.

Como terceira classe, os créditos tributários não se submetem à habilitação no processo de falência, na forma do art. $187^{15}$ do CTN.

Embora estes créditos não tenham que ser habilitados, os mesmos devem ser incluídos no quadro geral de credores, e na prática, é recomendável que o juiz da falência dirija ofício ao juízo da execução fiscal solicitando que do produto da venda do bem, sob constrição judicial, seja remetido o necessário para o atendimento dos créditos trabalhistas, créditos com garantia real, com prioridades sobre o crédito fiscal.

Por derradeiro, o Estado, por sua administração direta ou indireta, conserva-se como credor e, destarte, poderá pedir que o critério seja inscrito no quadro geral de credores, porém, deverá fazêlo na classe respectiva, que variará caso a caso, dependendo da natureza do respectivo crédito.

Aliás, o texto sancionado em 2005, na visão de muitos estudiosos da matéria, encerra inegável pretensão do legislador constituído em beneficiar empresas e instituições financeiras, em detrimento dos interesses da Fazenda Pública, e demais credores no processo de falência. Para outros, tratase de um instrumento eficaz e moderno no processo de recuperação das empresas inadimplentes, e que motiva tanto o investimento financeiro dos bancos, quanto à estabilidade e crescimento do setor econômico. Essas posições já são suficientes para se sentir o esforço e divergências dos operadores do direito na assimilação das regras do processo de falência.

\footnotetext{
${ }^{13}$ Art. 139. O crédito tributário decorre da obrigação principal e tem a mesma natureza desta.

${ }^{14}$ Art. 186. O crédito tributário prefere a qualquer outro, seja qual for a natureza ou o tempo da constituição deste, ressalvados os créditos decorrentes da legislação do trabalho.

${ }^{15}$ Art. 187. A cobrança judicial do crédito tributário não é sujeita a concurso de credores ou habilitação em falência, concordata, inventário ou arrolamento.
} 
Porém, se analisada a questão pelo prisma da função social da empresa, com a garantia de que os credores com garantia terão preferência até mesmo contra o Fisco, se revela a função social na falência, pois fomenta o investimento financeiro dos bancos, e consequentemente, o crescimento economico, tendo este sido o escopo da lei.

\section{Dos créditos com privilégio especial}

Resolvidas as preferências anteriores, serão pagos os créditos com privilégio especial, e estes créditos são oriundos de obras, benfeitorias, entre os outros direito de créditos regulados pelo art. $964^{16}$ do Código Civil Brasileiro, que não se definem sobre o patrimônio do falido, mas sobre bens em espécie.

Dos ensinamentos clássicos de Carvalho de Mendonça, ressalta Sérgio Campinho que o nobre doutrinador dimensionava esses créditos, como conseqüência de situações diversas em que se poderia achar o credor, cada uma das quais com motivações e regras próprias, e o direito de preferência que resulta de um privilégio especial se diferiria do proveniente de um direito real (CAMPINHO, 2008).

Ainda, continua o nobre doutrinador, frisando que "os bens sobre os quais recai o privilégio não ficam direta e imediatamente vinculados ao cumprimento da obrigação. $\mathrm{O}$ devedor pode deles dispor livremente, enquanto não forem judicialmente seqüestrados, penhorados ou arrecadados" (CAMPINHO, 2008, p. 415).

Desse modo, verifica-se que os privilégios especiais resultam de regras de ordem pública e sua interpretação não admite ampliação, sendo obstado às partes sobre eles convencionarem.
Exemplificando, assim sustenta Gladston Mamed sobre os créditos por benfeitoria, estabelecido no inciso III do artigo. 964 do diploma legal em análise:

Assim, o privilégio dos créditos por benfeitorias necessárias ou úteis faz-se sobre a coisa beneficiada, da mesma forma a preferência do crédito do titular do direito autoral, pelo crédito fundado no contrato de edição, faz-se sobre os exemplares da obra existente na massa do editor. Vencidas as forças de bens ou direitos garantidores de tais relações, conforme o valor pelo qual tenham sido vendidos ou, se houve venda em bloco da empresa ou estabelecimento, pelo valor de sua avaliação, o restante do crédito se classificará e será eventualmente pago como quirografário. (MAMEDE, 2006, p. 588).

Com efeito, após os ilustre ensinamento destacado, fica claro que o escopo do legislador é estabelecer um critério específico ao pagamento dos créditos dos credores com garantia especial, vez que é comum na prática comercial, negócios jurídicos da empresa ainda não falida com credores de obras, aluguéis, tendo com este mecanismo uma preferência de pagamento após as classes anteriores.

\section{Créditos com privilégio geral}

Assim como nos créditos com privilégio especial, o legislador buscou também assegurar a preferência de pagamento certos credores, formando mais uma classe, esta como privilégio geral, entre os outros direitos de créditos regulados pelo art. $965^{17}$ do Código Civil Brasileiro.

Sem delongas, esses créditos obedecem ao mesmo critério dos créditos com privilégio especial, e pelos termos dos artigos aludidos, estes créditos não podem ser confundidos com os créditos quirografários. Se não houver recursos suficientes para a satisfação de todos os credores dessa classe, far-se-á o rateio entre eles, ou seja, os valores serão repartidos proporcionalmente à importância dos créditos de cada um dos integrantes.

\footnotetext{
${ }^{16}$ Art. 964. Têm privilégio especial:

I - sobre a coisa arrecadada e liquidada, o credor de custas e despesas judiciais feitas com a arrecadação e liquidação;

II - sobre a coisa salvada, o credor por despesas de salvamento;

III - sobre a coisa beneficiada, o credor por benfeitorias necessárias ou úteis;

IV - sobre os prédios rústicos ou urbanos, fábricas, oficinas, ou quaisquer outras construções, o credor de materiais, dinheiro, ou serviços para a sua edificação, reconstrução, ou melhoramento;

$\mathrm{V}$ - sobre os frutos agrícolas, o credor por sementes, instrumentos e serviços à cultura, ou à colheita;
} 


\section{Créditos quirografários}

Se a massa falida ainda tiver forças, após os pagamentos dos créditos das classes anteriores, o administrador judicial passará ao pagamento dos créditos quirografários, que são tidos como credores sem garantia ou qualquer forma de privilégio especial ou geral para o crédito.

Antes de qualquer fundamentação, importa dimensionar o significado de quirografário, como bem delimita sua origem Marcelo M. Bertoldi e Márcia Ribeiro:

A origem da palavra quirografário está associada a algo que foi escrito. Os credores quirografários são aqueles cuja única garantia é um escrito. São aqueles credores que não têm garantia específica - a totalidade do patrimônio do devedor responde pelas obrigações. Como na hipótese de falência presumivelmente o patrimônio não será suficiente, a posição dos credores quirografários é pouco confortável na falência, uma vez que a perspectiva de recebimento é negativa (BERTOLDI; RIBEIRO, 2008, p. 698).

Logo, os credores quirografários somente serão satisfeitos depois de todos os demais credores, anteriores apenas aos subquirografários e aos subordinados, e como não possuem título legal de preferência, tem o mesmo direito que os outros credores, nas mesmas condições sobre os bens do devedor comum, sendo pagos em rateio do saldo que houver.

Oalcance da definição dos créditos quirografários, em face da estipulação inscrita no art. 83, VI, a, da Lei 11.101/2005, pode ser assim dimensionada: títulos de crédito, incluindo aqueles que decorram do direito de regresso por parte de coobrigados, credores por contratos sem garantia real,credores que tenham seus créditos comprovados por prova escrita, sem a qualidade de título executivo e, até, credores por relações jurídicas ilíquidas, entre outros.

Ainda importa ressaltar que os créditos trabalhistas excedentes a 150 (cento e cinquenta) salários mínimos serão recepcionados por esta ordem, e, muitas vezes, na prática, muitos dos credores quirografários nunca recebem seus créditos, tendo em vista que o ativo não é suficiente para possibilitar a condição do pagamento de tais créditos, motivos da grande polêmica que surgiu com a Lei 11.101/2005, quanto à limitação dos créditos trabalhistas em 150 salários mínimos, como amplamente discutida em capítulos anteriores; Esse posicionamento já está consolidado pelo Supremo Tribunal Federal, como já estudado.

\section{Dos créditos subquirografários e subordinados}

Os créditos subquirografários são os créditos oriundos de atos ilícitos, ou seja, as multas contratuais e as penas pecuniárias por infração das leis penais ou administrativas, inclusive as multas tributárias, previstas no art. 83 , inciso VII ${ }^{18}$, da Lei $11.101 / 05$.

As multas sejam contratuais, tributárias, ou decorrentes de infrações penais ou administrativas têm natureza indenizatória, a rigor só sendo pagas se os bens da massa falida forem suficientes.

Além disso, os créditos subordinados são créditos sub-quirografários, estando, portanto, também na última escala dos créditos na falência.

São dessa espécie os créditos decorrentes de debêntures subordinadas, também denominadas "subquirografárias", que não gozam de qualquer garantia expressamente previstas no art. 58, $\S 4^{\mathrm{o} 19}$, da Lei no 6.404/76 (Lei das Sociedades Anônimas).

VI - sobre as alfaias e utensílios de uso doméstico, nos prédios rústicos ou urbanos, o credor de aluguéis, quanto às prestações do ano corrente e do anterior;

VII - sobre os exemplares da obra existente na massa do editor, o autor dela, ou seus legítimos representantes, pelo crédito fundado contra aquele no contrato da edição;

VIII - sobre o produto da colheita, para a qual houver concorrido com o seu trabalho, e precipuamente a quaisquer outros créditos, ainda que reais, o trabalhador agrícola, quanto à dívida dos seus salários.

${ }^{17}$ Art. 965 . Goza de privilégio geral, na ordem seguinte, sobre os bens do devedor:

I - o crédito por despesa de seu funeral, feito segundo a condição do morto e o costume do lugar; 
Da mesma espécie é o eventual direito de acionistas e diretores na partilha da sociedade falida.

Nesta toada (Nesse sentido), o legislador optou por estabelecer o pagamento dos acionistas e diretores da massa somente após todos os pagamentos jungidos no Quadro Geral de Credores, vez que seria injusto que algum acionista recebesse seus créditos antes de qualquer credor preferencial.

Ademais, nesta última classe se veem credores que deram causa à falência, por má administração ou incorrem no risco empresarial, motivo pelo qual o pagamento com o que sobejar do ativo torna-se justo, e ao mesmo tempo injusto, porquanto é bem provável que estes últimos credores não recebam nada dos créditos relacionados na ordem de pagamento.

\section{Conclusão}

Após o desenvolvimento deste estudo podem ser alinhavados alguns comentários salutares sobre a nova classificação dos créditos pela Lei 11.101/2005.

Pois bem, é cediço que a nova ordem de pagamento quebrou paradigmas no instituto da falência, visto que os créditos que antes tinham super privilégios foram relegados, como se percebe, em relação aos créditos trabalhistas, porém, como escopo de garantir o pagamento dos demais credores, em evidente cumprimento à função social.

Dessarte, não se pode olvidar que a Lei 11.101/2005 trouxe avanços consideráveis, e proporcionou ao ordenamento jurídico brasileiro a instrumentalização da função social da empresa, respeitando de forma veemente a par conditio creditorum e o princípio da viabilidade da empresa no que pertine a criação do instituto da Recuperação Judicial.

Com efeito, a Lei 11.101/2005 operou uma quebra de paradigma na ordem classificatória, que foi a criação polêmica limitação dos créditos trabalhistas, porém, está claro que o entendimento do Supremo Tribunal Federal é pela constitucionalidade da limitação epigrafada, tendo em vista, como sustentou o Ministro Ricardo Lewandowski, que a limitação está amparada pelas convenções mundiais em matéria de direito do trabalho, e que o Brasil ratificou este entendimento ao entabular a aplicar a limitação na lei atual.

Desta feita, a classificação dos creditos pela Lei $11.101 / 2005$ efetivamente cumpre a função social da empresa na falência, pois garante eficácia ao recebimento de valores por diversos credores, visto que, pela legislação anterior, muitos credores tinham seus créditos comprometidos em face do superprilégio dos créditos trabalhistas, sendo necessária a alteração da legislação em respeito à função social da empresa, que comtempla o respeito a todos os credores, investidores, e não somente aos trabalhadores.

II - o crédito por custas judiciais, ou por despesas com a arrecadação e liquidação da massa;

III - o crédito por despesas com o luto do cônjuge sobrevivo e dos filhos do devedor falecido, se foram moderadas;

IV - o crédito por despesas com a doença de que faleceu o devedor, no semestre anterior à sua morte;

$\mathrm{V}$ - o crédito pelos gastos necessários à mantença do devedor falecido e sua família, no trimestre anterior ao falecimento;

VI - o crédito pelos impostos devidos à Fazenda Pública, no ano corrente e no anterior;

VII - o crédito pelos salários dos empregados do serviço doméstico do devedor, nos seus derradeiros seis meses de vida;

VIII - os demais créditos de privilégio geral.

${ }^{18}$ Art. 83. A classificação dos créditos na falência obedece à seguinte ordem:

VII - as multas contratuais e as penas pecuniárias por infração das leis penais ou administrativas, inclusive as multas tributárias;

${ }^{19}$ Art. 58. A debênture poderá, conforme dispuser a escritura de emissão, ter garantia real ou garantia flutuante, não gozar de preferência ou ser subordinada aos demais credores da companhia.§ $4^{\circ}$ - A debênture que não gozar de garantia poderá conter cláusula de subordinação aos credores quirografários, preferindo apenas aos acionistas no ativo remanescente, se houver, em caso de liquidação da companhia. 


\section{Referências}

APPROBATO, R. Comentários à nova lei de falências e recuperação de empresas. 2. ed. São Paulo: Quartier Latin, 2006.

BALEEIRO, A. Direito tributário brasileiro. 10. ed. Rio de Janeiro: Forense, 1991.

BERTOLDI, M. M.; RIBEIRO, M. C. P. Curso avançado de direito comercial. 4. ed. São Paulo: Revista dos Tribunais, 2008.

BRASIL, Superior Tribunal de Justiça. Recurso Especial n. 32.959/S. Rel. Min. Eduardo Ribeiro, j. 13-8-1997. Disponível em: < https://ww2.stj. jus.br/docs_internet/revista/eletronica/stj-revistasumulas-2011_16_capSumula219.pdf $>$. Acesso em: 15 abr. 2010.

BRASIL. PLC $n^{\circ} 71$, de 2003. Da comissão de constituição, justiça e cidadania sobre o PLC $n^{\circ} 71$, de 2003, que regula a recuperação judicial, a extrajudicial e a falência de devedores pessoas físicas e jurídicas que exerçam atividade econômica regida pelas leis comerciais, e dá outras providências. Disponível em: $<$ http://www.senado. gov.br/atividade/materia/getPDF.asp? $\mathrm{t}=27351>$. Acesso em: 15 abr. 2010.

BRASIL. Lei $n^{\circ}$ 3.726, de 11 de fevereiro de 1960. Altera os arts. 102 e 124 da Lei de Falências para dar prioridade aos créditos trabalhistas. Disponível em: <http://www.planalto.gov.br/ccivil_03/leis/ L3726.htm>. Acesso em: 15 abr. 2010.

CAMPINHO, S. Falência e recuperação de empresa: o novo regime da insolvência empresarial. 3. ed. Rio de Janeiro: Renovar, 2008.

COELHO, F. U. Comentários à nova lei de falências e de recuperação de empresas. 6. ed. São Paulo: Forense, 2008.

. Curso de direito comercial. São Paulo: Saraiva, 2000. v. 3.

LUCCA, N.; SIMÃO FILHO, A. (Coord.). Comentários à nova lei de recuperação de empresas e de falências. São Paulo: Quartier Latin, 2005.

MAMEDE, G. Falência e recuperação de empresas. São Paulo: Atlas, 2006. v. 4.

MARTINS, S. P. A nova lei de falências e suas implicações nos créditos dos trabalhadores. Revista
IOB Trabalhista e Previdenciária, Porto Alegre, v. 17, n. 215, p. 7-14, maio 2007.

NEGRÃO, R. Manual de direito comercial de empresa. São Paulo: Saraiva, 2007. v. 3.

REQUIÃO, R. Curso de direito falimentar. 14. ed. São Paulo: Saraiva, 1998.
Recebido em: nov. 2011

Aceito em: dez. 2011 
